\title{
Instytucje finansowe i ubezpieczeniowe jako podmioty ekonomii społecznej w Galicji - zarys problematyki
}

\author{
Krzysztof Broński*
}

\begin{abstract}
Streszczenie: Galicja była najbardziej zacofaną prowincją w monarchii habsburskiej. W strukturze społeczno-gospodarczej tego regionu dominowała ludność wiejska, utrzymująca się z niewielkich gospodarstw rolnych. Występujące w Galicji klęski żywiołowe, zwłaszcza powodzie i pożary, pogłębiały zubożenie społeczeństwa. Powstające podmioty ekonomii społecznej były próbą pomocy różnym grupom społecznym, w szczególności ludności wiejskiej. W szkicu przedstawiono genezę powstania oraz funkcjonowanie spółdzielczych instytucji finansowych oraz towarzystw ubezpieczeń wzajemnych w Galicji w drugiej połowie XIX w. Próba oceny rezultatów działalności spółdzielczych instytucji finansowych pokazała ich istotną rolę w przeciwdziałaniu lichwie i wspieraniu rozwoju drobnych gospodarstw rolnych oraz rzemiosła poprzez udostępnienie taniego kredytu. W latach 60. XIX w. w Krakowie powstało Towarzystwo Wzajemnych Ubezpieczeń "Florianka”. Instytucja ta przed I wojną światową była jednym z największych tego typu Towarzystw na świecie. Ponadto powstały i prowadziły działalność w Galicji Towarzystwa Wzajemnych Ubezpieczeń: „Wisła”, „Dnister" i „Karpatia”.
\end{abstract}

Słowa kluczowe: Galicja, spółdzielczość kredytowa, towarzystwo ubezpieczeń wzajemnych, ekonomia społeczna, kasy brackie.

\section{Wprowadzenie}

Galicja uchodziła za najbardziej zacofaną prowincję monarchii habsburskiej. Wieś galicyjską szczególnie silnie dotykało zjawisko ubóstwa. Wśród wielu czynników rzutujących wówczas na złą sytuację gospodarczą kraju wskazuje się przede wszystkim brak rozwiniętego rynku wewnętrznego. W strukturze gospodarczej Galicji dominowało rolnictwo z przewagą drobnych gospodarstw. W latach 60. XIX w. dawało ono utrzymanie dla ok. 80\% ludności. W kolejnych dekadach sytuacja ta nie uległa istotnej zmianie i w 1910 r. prawie 3/4 z $8 \mathrm{mln}$ ludności utrzymywało się z tego działu gospodarki. Wieś żyła w skrajnym ubóstwie spowodowanym przeludnieniem, niskim stanem techniki rolnej, małymi możliwościami produkcji towarowej. Dotkliwym problemem ekonomicznym i społecznym była lichwa spo- wodowana brakiem dostępu do taniego kredytu zarówno dla małorolnych włościan, jak też dla drobnych rzemieślników. Dodatkowo zubożenie powodowały nawiedzające kraj klęski żywiołowe. Powstające w Galicji podmioty ekonomii społecznej były odpowiedzią na sytuację społeczno-gospodarczą tych ziem.

Celem szkicu jest próba otwarcia dyskusji nad problematyką funkcjonowania instytucji ekonomii społecznej w Galicji w drugiej połowie XIX w. Analizie poddane zostaną te instytucje finansowe oraz przedsiębiorstwa ubezpieczeń wzajemnych, które w tym okresie powstały i znacznie rozwinęły swoją dzia-

\footnotetext{
* Krzysztof Broński

Katedra Historii Gospodarczej i Społecznej

Uniwersytet Ekonomiczny w Krakowie

ul. Rakowicka 27, 31-510 Kraków

e-mail:bronskik@uek.krakow.pl
} 
łalność. W szczególności przybliżone zostanie funkcjonowanie spółdzielczych kas oszczędnościowo-kredytowych a także Towarzystwa Wzajemnych Ubezpieczeń „Florianka” w Krakowie.

\section{Spółdzielczość kredytowa}

Ważną rolę w rozwoju rolnictwa spełniał kredyt. Do czasu uwłaszczenia w 1848 r. włościanie galicyjscy byli pozbawieni dostępu do kredytu. W latach 60. i 70. XIX w. korzystali oni z kredytu udzielanego przez żydowskich lichwiarzy, którzy oferowali pożyczki najczęściej na 50-100\% rocznie, ale były też przypadki oprocentowania wyższego. W okresie 1873-1894 z powodu niewypłacalności zlicytowano prawie 50 tys. gospodarstw chłopskich, dla których oferta banków prywatnych była nieosiągalna. Szansę dla nich stwarzała organizacja spółdzielczych kas oszczędnościowo-kredytowych. Spółdzielczość tego rodzaju rozwijała się w Galicji od lat 60. XIX w. Jej idea dotarła z Niemiec, gdzie złe położenie ludności wiejskiej i miejskiej w połowie XIX w. oraz szerząca się lichwa spowodowały powstanie spółdzielczych organizacji kredytowych. Wykształconą formę spółdzielczości kredytowej posiadały dopiero stowarzyszenia, których organizatorami byli: Franz Herman Schulze z Delitzsch, zakładający w miastach spółdzielnie kredytowe dla drobnomieszczaństwa i Friedrich Wilhelm Raiffeisen, prowadzący analogiczną działalność dla drobnych rolników. Działaczom tym zależało na uniezależnieniu drobnych wytwórców od lichwiarskiego kredytu. Uniezależnienie to dokonywało się przez zrzeszenie przyszłych pożyczkobiorców we własnych spółdzielniach kredytowych niezależnych od banków. Przyjęto zasadę ograniczania wysokości odsetek od udzielanych kredytów. Obydwa typy spółdzielczych instytucji finansowych występowały w Galicji. Formalne unormowanie zasad funkcjonowania spółdzielczości kredytowej nastąpiło w 1873 r., zaś ustawa z 1903 r. uregulowała kwestię kontroli państwa nad stowarzyszeniami zarobkowymi i gospodarczymi. Prototypem towarzystwa zaliczkowego systemu Schulzego było założone we Lwowie w 1860 r. „Stowarzyszenie Wzajemnej Pomocy Rękodzielników Mieszczan Lwowskich pw. bł. Jana z Dukli". W 1864 r. powstało w Brzeżanach Miejskie Towarzystwo Zaliczkowe, a w 1869 r. w Krakowie. Przed 1873 r. w Galicji funkcjonowało 16 stowarzyszeń tego typu. Przyspieszony rozwój tych towarzystw datuje się od powstania w 1874 r. Związku Stowarzyszeń Zarobkowych i Gospodarczych. Przed wybuchem I wojny było w Galicji 238 spółdzielni typu Schulzego zrzeszonych w tym związku, które w 1912 r. dysponowały kapitałem w wysokości około 58,8 mln koron. Natomiast liczba towarzystw niezrzeszonych wynosiła 1340, a ich kapitał obejmował 49,9 mln koron [Witalec, 2008, s. 135-136, 155-156]. Były to instytucje klasy średniej (rzemieślników, kupców, urzędników i przedstawicieli wolnych zawodów).

Wielokulturowość Galicji miała swe odzwierciedlenie również w rozwoju spółdzielczości kredytowej. Dominujące w Galicji trzy grupy etniczno-narodowościowe: Polacy, Ukraińcy i Żydzi tworzyły również odrębne instytucje finansowe tego rodzaju.

W 1873 r. powstał wspólny Zakład Kredytowy dla Galicji i Bukowiny, będący pierwszą spółdzielnią ukraińską. Zakład ten przetrwał do 1883 r. W 1894 r. została założona spółdzielnia - Towarzystwo Wzajemnego Kredytu „Wira” w Tyśmienicy koło Stanisławowa. Do końca XIX w. powstało kilkanaście dalszych tego typu instytucji finansowych. W 1898 r. spółdzielnie ukraińskie utworzyły związek rewizyjny - Krajewyj Sojuz Kredytowyj, zwany Centrobankiem. W 1914 r. działało w Galicji 428 ukraińskich stowarzyszeń kredytowych, które liczyły ponad 162 tys. członków. Dysponowały one kapitałami w wysokości 8,4 mln koron, a stan pożyczek kształtował się na poziomie 47,9 mln koron [Morawski, 1998, s. 69-70].

W 1876 r. powołano pierwszą żydowską spółdzielnię kredytową. W latach następ- 
nych powstawały kolejne spółdzielnie, które w 1901 r. założyły związek rewizyjny pod nazwą Powszechny Związek na Własnej Pomocy oparty Galicyjskich Stowarzyszeń Zarobkowych i Gospodarczych. Żydowskie kasy zaliczkowe, rozwijające się w środowisku drobnomieszczańskim, były na ogół mniej zasobne niż polskie. W 1914 r. działało w Galicji 912 żydowskich spółdzielni kredytowych. Dysponowały one kapitałem w wysokości 41,5 mln koron, a stan kredytów udzielonych wynosił 237,2 mln koron [Michalski, 1914, s. 55; Morawski, 1998, s. 70].

Funkcjonowanie stowarzyszeń kredytowych nie było pozbawione niedociągnięć organizacyjnych, co powodowało, że nie zaspokajały one w pełni popytu na kredyt rzemieślniczy. Rozwój stowarzyszeń kredytowych narzucał konieczność utworzenia dla nich centralnej instytucji finansowej. W 1902 r. powstała taka instytucja pod nazwą Akcyjny Bank Związkowy. Kapitał banku wynosił początkowo $1 \mathrm{mln}$ koron, w 1912 r. wzrósł on do 2,5 mln koron. Bank rozwijał się relatywnie szybko, bowiem jego portfel wynosił w 1912 r. 13,5 mln koron, różne pożyczki 2,7 mln koron, wkłady wynosiły 0,9 mln koron, zobowiązania na rachunkach bieżących 14,3 mln koron [Michalski, 1914, s. 52].

W 1875 r. dotknęła wieś galicyjską klęska nieurodzaju. Wówczas podjęto działania mające na celu zbadanie możliwości wprowadzenia w Galicji rozpowszechnionych w Austrii kas pożyczkowo-oszczędnościowych typu Raiffeisena. Wieś potrzebowała kas działających w ramach jednej gminy, według zasad uproszczonej rachunkowości. Kryteria te spełniały kasy Raiffeisena, których zakładanie rozpoczęło się w Galicji w latach 90. XIX w. Ich promotorem stał się Franciszek Stefczyk, który założył pierwszą spółkę oszczędności i pożyczek w Czernichowie w 1890 r. [Najdus, 1971, s. 174]. W następnych dziewięciu latach powstaje dalszych 25 spółek w różnych częściach kraju. Kasy te, które zaczęto nazywać „kasami Stefczyka", w 1899 r. objęło opieką Biuro Pa- tronatu przy Wydziale Krajowym'. Celem kas był materialny i moralny rozwój swych członków. Zadania te spółki realizowały pozyskując wkłady oszczędnościowe i udzielając taniego kredytu miejscowej ludności. Potrzeby oszczędzania wyprowadzano nie z zamożności, ale z ubóstwa [Skodlarski, 2010, s. 85]. Realizacja zadań kas wymagała posiadania funduszy obrotowych. W każdej kasie fundusz taki powstawał z udziałów członkowskich, wkładów oszczędnościowych, zaciąganych pożyczek, oraz opłat wstępnych i innych dochodów. Do statutowej działalności zarządu należało również zaciąganie pożyczek w granicach i na warunkach ustalonych przez walne zgromadzenie. Pożyczki mogły być zaciągane w innych instytucjach finansowych i u osób fizycznych, również wtedy, gdy nie były członkami spółki. Fundusze obrotowe spółki mogły być wykorzystane na udzielanie pożyczek i pokrywanie kosztów administracyjnych. Pożyczek udzielał zarząd, w granicach ustalonych uchwałą walnego zgromadzenia. Specjalną formę pożyczki stanowił kredyt w rachunku bieżącym. Do realizacji tego kredytu potrzebne było posiadanie w kasie rachunku otwartego, na którym właściciel konta lokował posiadane fundusze. Stopa procentowa od udzielanych pożyczek nie mogła przewyższać stopy od wkładów oszczędnościowych o więcej niż 1,5\%. Odsetki od pożyczek były zawsze pobierane z dołu. Jeżeli bilans kasy zamykał się stratą, podlegała ona pokryciu z majątku spółki, tzn. z jej funduszu rezerwowego. Trzeba podkreślić, że dobre wyniki finansowe kasy zawdzięczały stosowaniu wypracowanych zasad zdrowej gospodarki finansowej [Górnicz, 1976, s. 100]. Nowa organizacja spółdzielcza wykazała swą przydatność w warunkach wiejskich. Ważną okolicznością wpływającą na wzrost popularności „raiffeisenek" była dostępność do nich mieszkańców wsi i małych miast. W okresie 1900-1914 udzieliły one rolnikom pożyczek na

Wydział Krajowy był organem wykonawczym Sejmu Krajowego. 
kwotę 215, 3 mln koron [Twarecki, 1928, s. 9]. Ta suma znacznie ograniczyła lichwę na wsi, umożliwiała zakup inwentarza, maszyn rolniczych, nawozów sztucznych itp. Walka z lichwą była podstawowym celem ekonomicznym kas Stefczyka. Należy jednak podkreślić, że w odróżnieniu od towarzystw zaliczkowo-kredytowych typu Schulzego spełniały one także ważne zadania społeczne i wychowawcze, promując wśród rolników ideę oszczędzania, zasady racjonalnej gospodarki finansowej, obowiązkowość i słowność w sprawach kredytu czy też nawyk pracy dla innych. Kasy te wspierały także materialnie i moralnie rozwój innych form spółdzielczości, m.in. mleczarskiej i rolniczo-handlowej [Żukowska, 1989, s. 199, 203].

Dużą rolę odegrał również uprzednio wspomniany "Patronat" przy Wydziale Krajowym. Jego zaangażowanie dotyczyło szkoleń, działalności wydawniczej oraz pomocy organizacyjnej i finansowej w tworzeniu nowych spółdzielni. W 1912 r. pod „Patronatem" pozostawało 1334 spółki obejmujące swą działalnością 2/3 gmin Galicji². Wśród członków ponad 90\% stanowili rolnicy. W 1909 r. utworzono dla nich rodzaj centrali finansowej (instytucji kredytującej) pod nazwą Centralna Kasa Spółek Rolniczych we Lwowie. Powołana instytucja była zakładem krajowym, a jej podstawowe fundusze obrotowe pochodziły z wkładów spółek na rachunek bieżący. Suma tych wkładów wynosiła w 1911 r. prawie 11,5 mln koron, w roku następnym z powodu przesilenia ekonomicznego i groźby wojny spadła do 9,3 $\mathrm{mln}$ koron. Kasa korzystała z kredytu bankowego na dogodnych warunkach w Banku Krajowym ${ }^{3}$. Instytucja ta posiadała również gwarancję Wydziału Krajowego za obce fundusze do wysokości $5 \mathrm{mln}$ koron [Michalski, 1914, s. 68].

Poza „Patronatem" działało 65 spółek, w tym 37 niemieckich i 24 ukraińskie, o łącznej liczbie 9171 członków [Michalski, 1914, s. 67].

Bank Krajowy był instytucją finansową utworzoną w 1883 r. we Lwowie przez Sejm Krajowy.

\section{Komunalne kasy oszczędności i kasy pożyczkowe}

Wśród instytucji finansowych ekonomii społecznej w Galicji, oprócz spółdzielczości oszczędnościowo-kredytowej, wspomnieć należy również o bankowości komunalnej. Opierała ona swoje funkcjonowanie zasadniczo na dwóch filarach. Jednym był samorząd terytorialny, który zwykle odgrywał istotną rolę w tworzeniu instytucji bankowej. Natomiast drugim filarem był określony model funkcjonowania instytucji, a także środowisko, do którego kierowana była oferta [Basta, 2013, s. 5]. Geneza bankowości komunalnej wiąże się z powstaniem kas oszczędności, które miały być instytucjami pozwalającymi na bezpieczne lokowanie niewielkich środków finansowych. Nie stosowały one zasady maksymalizacji zysku, lecz kierowały się długofalowym interesem klientów. Były instytucjami bezpiecznymi, co wynikało z włączenia ich w struktury związku komunalnego. Roczny zysk netto kas miał być przeznaczony przede wszystkim na tworzenie ich funduszu rezerwowego. Dopiero gdy fundusz ten osiągnął określoną w statucie kwotę część zysku, można było go przeznaczyć na cele charytatywne lub innego dobra publicznego [Buzek, 1913, s. 722]. Funkcje, jakie wyznaczono kasom, a także ich humanitarny charakter oraz niekomercyjna i bezpieczna działalność czyniły z nich organizacje mające charakter instytucji społecznych [Basta, 2013, s. 48; Zamoyski, 2013, s. 20]. Wzorem dla ich tworzenia była założona z inicjatywy Sejmu Stanowego we Lwowie w 1844 r. Galicyjska Kasa Oszczędności. W późniejszym okresie powstawały kasy oszczędności miejskie i powiatowe, m.in. w: Tarnowie (1861 r.), Rzeszowie (1862 r.), Samborze (1864 r.), Stryju (1867 r.), Przemyślu i Stanisławowie (1868 r.). W latach 1895-1900 powstało kolejnych 15 kas oszczędności. Z końcem 1912 r. funkcjonowały w Galicji 53 kasy oszczędności, w tym 24 miejskie, 28 powiatowych i 1 ukraińska, w których swoje 
oszczędności w kwocie 323 mln koron ulokowało 331,9 tys. klientów. W tym samym okresie kasy udzieliły pożyczek w wysokości 248,4 mln koron. W ciągu całego okresu funkcjonowania przeznaczyły one ponad $7 \mathrm{mln}$ koron na cele charytatywne, finansując powstanie i istnienie licznych instytucji humanitarnych i dobroczynnych [Michalski, 1914, s. 36, 40].

Od końca lat 60. XIX w. nastąpił w Galicji intensywny rozwój gminnych i powiatowych kas pożyczkowych. W rezultacie tego procesu w 1902 r. funkcjonowało już 3746 gminnych kas pożyczkowych z kapitałem 16,34 mln koron. Natomiast w 1895 r. było 15 kas powiatowych. Jednak wraz z rozwojem ilościowym tych instytucji nie szła jakość ich działania. Niektóre z tych kas pobierały wysokie odsetki, udzielały też kredytów, które ze względu na sytuację materialną dłużników były nieściągalne. Stąd też większość kas po rozpożyczeniu swoich kapitałów funkcjonowała tylko formalnie. Były to instytucje, które w pierwotnym założeniu nosiły pewne charakterystyki podmiotów ekonomii społecznej (tani kredyt dla włościan), jednak w ciągu ich dalszego rozwoju zatraciły swoje cele leżące u podstaw ich działania [Buzek, 1913, s. 671-672].

\section{Instytucje ubezpieczeń wzajemnych}

Drugim ważnym obszarem działalności podmiotów ekonomii społecznej w Galicji był rynek ubezpieczeń. Pierwotną przyczyną powołania tego typu instytucji były nękające kraj klęski żywiołowe (pożary, gradobicia), powodujące ogromne straty materialne, a w sferze społecznej konieczność zapewnienia pracownikom i ich rodzinom świadczeń na wypadek choroby, kalectwa czy też śmierci. Inicjatorem utworzenia towarzystwa ubezpieczeniowego opartego na wzajemności był Franciszek Trzecieski ${ }^{4}$. Starania w tym zakresie podjął

Franciszek Trzecieski (1805-1875), oficer, powstaniec listopadowy i styczniowy, działacz gospodarczy i polityczny, poseł do parlamentu austriackiego. on jeszcze w pierwszej połowie XIX w., które ostatecznie zakończyły się sukcesem w 1860 r., kiedy to władze wiedeńskie wydały koncesję na utworzenie w Krakowie Towarzystwa Wzajemnych Ubezpieczeń. Za godło Towarzystwo przyjęło św. Floriana, stąd popularna nazwa Towarzystwa - „Florianka” [Biskupski, 1925, s. 28]. Z początku istniał w Towarzystwie tylko dział ubezpieczeń od ognia. Po pokonaniu pierwszych trudności, tym większych, że rozpoczęto działalność o charakterze pionierskim, w 1864 r. wprowadzono ubezpieczenia gradowe, w 1869 r. - ubezpieczenia na życie, w 1877 r. - pogrzebowe, od szkód wynikłych z powodu wybuchu kotłów gazowych, uderzenia piorunów, kradzieży, nieszczęśliwych wypadków, odpowiedzialności cywilnej, szkód wodociągowych. W 1910 r. następuje rozszerzenie ryzyk o ubezpieczenie od wybuchu samochodów w podróży.

Pierwszymi członkami Towarzystwa byli przede wszystkim wielcy właściciele ziemscy. Jednak dla innych grup społeczeństwa było ono otwarte, gdyż statut nie przewidywał pod tym względem żadnych ograniczeń. Sformułowana w statucie Towarzystwa zasada wzajemności rozumiana była $w$ ten sposób, że odpowiedzialność członków za zobowiązania Towarzystwa obejmowała tylko tych, którzy ubezpieczali nieruchomości w Towarzystwie w danym roku.

W 1911 r. "Florianka” obchodziła jubileusz półwiecza działalności. W ciągu tego okresu dokonała $12 \mathrm{mln}$ ubezpieczeń od ognia, zebrała 281 mln koron składek, wypłaciła 172 mln koron odszkodowań [Doerman, 1911, s. 240]. „Florianka” prowadziła również działania mające na celu poprawę bezpieczeństwa ogniowego w Galicji. Tworzyła specjalne fundusze na popieranie fabryk dachówek, budowę wodociągów, udzielała pożyczek gminom na zakup pomp strażackich ${ }^{5}$. Inwestowała również w rozwój kadry dla potrzeb systemu

Ustanowiony w 1904 r. fundusz wynosił 1 mln koron, w 1910 r. został podwyższony do 1,3 mln koron. Ponadto "Florianka” wspierała różne filantropijne przedsięwzięcia. 
ubezpieczeń społecznych i gospodarczych. Pod względem innowacyjności „Florianka” wyprzedziła wszystkie towarzystwa wzajemnych ubezpieczeń i konkurencyjne towarzystwa akcyjne działające w Austrii. Do innowacji wprowadzonych przez "Floriankę" należały m.in.: zasada przystępowania do instytucji o każdym czasie, zawieranie ubezpieczeń na okres miesięczny. Jako jedno z pierwszych Towarzystw realizowała ona zasadę, że ubezpieczenie ważne było z chwilą złożenia opłaty zadatkowanej i na taki czas, w jakim stosunku była realnie złożona suma do umówionej opłaty. Starania TWU „Florianka” w Krakowie o udzielenie koncesji ze strony rządu rosyjskiego na rozszerzenie ubezpieczeń od ognia w Królestwie Polskim nie przyniosły skutku. W 1870 r. zawarto umowy reasekuracyjne z towarzystwami "Concordia”, "Securitas”, "Ceres”, „Europa” i "Morawsko-Śląskim”. W 1879 r. po przejęciu przedmiotu działań Galicyjskiego Towarzystwa Ubezpieczeń, TWU „Florianka" było jedyną krajową instytucją ubezpieczeń w Galicji. W dziale ubezpieczeń od gradobicia, z uwagi na liczne zgłoszenia szkód drobnych, powodujące duże obciążenie funduszu ubezpieczeniowego kosztami likwidacji i wypłatami licznych odszkodowań, TWU „Florianka" zastosowało po raz pierwszy w 1886 r. franszyzę integralną. W przededniu I wojny światowej „Florianka” była jedną z największych na świecie instytucji ubezpieczeniowych opartych na zasadzie wzajemności [Biskupski, 1925, s. 31-32]. Globalna suma ubezpieczenia wynosiła wówczas prawie 2,4 mld koron, fundusze rezerwowe ponad $62 \mathrm{mln}$ koron, a około 600 tys. ubezpieczeń przynosiło wraz z odsetkami od lokat prawie $23 \mathrm{mln}$ koron rocznych wpływów. Największe wpływy pochodziły z ubezpieczeń od ognia. W 1913 r. przekroczyły one 14,1 mln koron, z tytułu ubezpieczenia na życie składki wyniosły wówczas 5,1 mln koron. Zarząd TWU „Florianka” postanowił utworzyć instytucję kredytową opartą na zasadzie wzajemności. W 1873 r. zgromadzenie ogólne TWU uchwaliło projekt statutu Towarzystwa Wzajemnego Kredytu, które wraz z "Florianką" miało wspólną dyrekcję i zarząd, tworząc razem od 1874 r. zespół bankowo-ubezpieczeniowy.

W 1892 r. powstało Ukraińskie Towarzystwo Wzajemnych Ubezpieczeń „Dnister", które działało wyłącznie w zakresie ubezpieczeń od ognia. W ciągu 25 lat działalności to Towarzystwo wystawiło blisko $4 \mathrm{mln}$ polis, zebrało 41 mln koron składek oraz wypłaciło $21 \mathrm{mln}$ koron odszkodowań [Biskupski, 1925, s. 35].

W 1909 r. galicyjski przemysłowiec i polityk Władysław Długosz założył Towarzystwo Wzajemnych Ubezpieczeń „Wisła”. Ta instytucja adresowała swoją ofertę ubezpieczenia od ognia do rolników. W pierwszym roku istnienia „Wisła” wystawiła 9645 polis, w 1914 r. już 48283 polisy. Wartość ubezpieczona wzrosła z 17,6 mln koron (w 1909 r.) do 76,2 mln koron (w 1914 r.). W okresie 1909-1914 Towarzystwo zebrało 2,5 mln koron składek. Od założenia Towarzystwa do końca 1914 r. wypłacono 1415 odszkodowań na kwotę 1,318 mln koron [Sprawozdanie „Wisły", b.r.w., s. 12, 17].

W 1911 r. dzięki staraniom lwowskiego metropolity greckokatolickiego Andrzeja Szeptyckiego została założona „Karpatia” Towarzystwo Wzajemnych Ubezpieczeń na Życie i Renty. To Towarzystwo w 1913 r. zebrało 928 polis na sumę 2,785 mln koron [Biskupski, 1925, s. 35].

W zakresie ubezpieczeń społecznych funkcjonowały w Galicji kasy brackie. Organizację istniejących w monarchii habsburskiej takich instytucji unormowała ustawa górnicza z 1854 r. Kasy te były obowiązkowe dla przedsiębiorstw górniczych oraz kopalń wosku ziemnego i asfaltu. Przemiana tych kas w rzeczywiste zakłady ubezpieczeń następowała etapami i zakończyła się w 1907 r. Każda kasa bracka posiadała wówczas dwa wydziały - kasę chorych i kasę prowizyjną. Kasy brackie realizowały niemal wszystkie ubezpieczenia społeczne z wyjątkiem ubezpieczenia na wypadek bezrobocia. W ramach kasy funkcjonowali członkowie o pełnych prawach i członkowie o prawach ograniczonych. Członkami przymusowymi 
o pełnych prawach byli wszyscy górnicy, zaś o prawach ograniczonych - urzędnicy górniczy tudzież robotnicy zatrudnieni przejściowo w kopalni celem budowy dróg, kolei, mostów itp. Dobrowolnie mogli się w kasie brackiej ubezpieczyć od choroby także członkowie rodziny górnika, wdowy i sieroty po członkach itp. Koszty ubezpieczenia przymusowego ponosili po połowie ubezpieczony i przedsiębiorca, zaś przy ubezpieczeniu dobrowolnym wyłącznie ubezpieczony. Należy zaznaczyć, że przymusowi członkowie o prawach ograniczonych byli w kasie ubezpieczeni tylko od choroby i wypadku, natomiast przymusowi członkowie o pełnych prawach nie tylko od choroby i wypadku, ale i na wypadek kalectwa. Wdowy i sieroty po członkach o pełnych prawach otrzymywały renty wdowie i sieroce. W 1910 r. w Galicji funkcjonowało 12 kas chorych kas brackich, łącznie z tymi przy kopalniach rządowych, w których ubezpieczonych było 10587 członków. Kas prowizyjnych brackich było również 12, liczba ubezpieczonych w nich członków o pełnych prawach wynosiła 9710, a o prawach ograniczonych - 864 [Buzek, 1913, s. 821-823].

\section{Podsumowanie}

W Galicji w drugiej połowie XIX w. powstawały i rozwijały swoją działalność instytucje ekonomii społecznej. Wśród nich największą rolę odegrały spółdzielnie oszczędnościowo-kredytowe oraz towarzystwa ubezpieczeń wzajemnych. Spółdzielczość w zaborze austriackim rozwijała się w warunkach prawnych gwarantujących względną swobodę stowarzyszania się. Spółdzielczość oszczędnościo-

\section{Literatura}

Basta J. (2013). Bankowość komunalna w Polsce w latach 1918-1948. Warszawa: NDAP.

Biskupski I. (1925). O ubezpieczeniach. Poznań: Fiszer i Majewski. wo-kredytowa powstawała najpierw w miastach, w formie towarzystw zaliczkowych typu Schulzego. Były to instytucje kredytowe klas średnich, kierujące swoją ofertę głównie do drobnych rzemieślników, kupców i urzędników. Na wsi natomiast rozwijała się z inicjatywy F. Stefczyka spółdzielczość kredytowa typu Raiffeisena, która z sukcesem realizowała swoją misję dostarczania taniego kredytu dla włościan. Oba typy instytucji stanowiły skuteczną ochronę przed zjawiskiem lichwy pieniężnej i towarowej. Również istotna była ich rola w krzewieniu kultury, dobroczynności czy też edukacji swoich członków.

Po 1860 r. powstawały i rozszerzały swoją działalność towarzystwa ubezpieczeń wzajemnych. Jako podmioty ekonomii społecznej stawiały sobie za cel zabezpieczenie ludności na wypadek klęsk żywiołowych jak i innych zdarzeń losowych. Wśród tych instytucji wiodącą rolę odegrało TWU „Florianka" jako przedsiębiorstwo najbardziej innowacyjne nie tylko w Galicji, ale także w Austrii. Tuż przed I wojną światową było to jedno z największych towarzystw ubezpieczeń wzajemnych na świecie. Oprócz szerokiej oferty ubezpieczeń prowadziło również działalność wspierającą ochronę przeciwpożarową i inwestowało w rozwój kadry dla systemu ubezpieczeń. Wśród instytucji ubezpieczeniowych w Galicji istotna była też działalność TWU „Wisła” oraz ukraińskiego TWU "Dnister", oferujących ubezpieczenia od ognia, oraz TWU „Karpatia", realizującego ubezpieczenia na życie. W zakresie ubezpieczeń społecznych w górnictwie funkcjonowały kasy brackie, które pod koniec XIX w. przekształcone zostały w zakłady ubezpieczeń.

Buzek J. (1913). Administracja gospodarstwa społecznego. Lwów: Nakładem Towarzystwa Nauczycieli Szkół Wyższych.

Doerman A. (1911). Towarzystwo Wzajemnych Ubezpieczeń w Krakowie 1861-1911. Księga pamiątkowa półwiekowej działalności. Kraków: W.L. Anczyc. 
Górnicz A. (1976). Franciszek Stefczyk. Życie, poglady, działalność. Warszawa: Zakład Wydawnictw CRS.

Michalski J. (red.) (1914). Polskie kooperatywy kredytowe i kasy oszczędności. Rozwój i stan obecny na obszarze ziem polskich. Lwów: Skład Główny w Księgarni Gubrynowicza i Syna we Lwowie.

Morawski W. (1998). Słownik historyczny bankowości polskiej do 1939 roku. Warszawa: MUZA SA.

Mroczka L. (1998). „Spółdzielczość kredytowa F.W. Raiffeisena w rolnictwie chłopskim w Galicji", Rocznik Naukowo-Dydaktyczny WSP W Krakowie, Prace Historyczne XIX, z. 193, s. 39-66.

Najdus W. (1971). "Zarys historii polskiego ruchu spółdzielczego w zaborze austriackim", w: S. Inglot (red.), Zarys historii polskiego ruchu spółdzielczego, cz. I do 1918 r. (s. 149-232). Warszawa: Zakład Wydawnictw CRS.

Rybarski R. (1911). Organizacja kredytu przemysłowego w Galicji i Królestwie Polskim. Kraków: Drukarnia Uniwersytetu Jagiellońskiego.
Skodlarski J. (2010). Franciszek Stefczyk (1861-1924). Pionier spółdzielczości kredytowej. Łódź: Uniwersytet Łódzki.

Sprawozdanie "Wisły" Ludowego Towarzystwa Wzajemnych Ubezpieczeń we Lwowie z działalności w szóstym i siódmym roku istnienia, tj. za czas od 1 stycznia 1914 do 31 grudnia 1914 i od 1 stycznia 1915 do 31 grudnia 1915 (b.r.w.). Nowy Sącz.

Twarecki L. (1928). Rola Kas Stefczyka w walce z lichwa na wsi. Lwów, Kraków, Warszawa: Wydawnictwo Zjednoczenia Związków Spółdzielni Rolniczych Rzeczypospolitej Polskiej.

Witalec R. (2008). Spółdzielczość kredytowa systemu Schulzego w Małopolsce w latach 1873-1939. Warszawa: Muzeum Historii Polskiego Ruchu Ludowego.

Zamoyski G. (2013). „Pracuj ioszczędzaj”. Kasy oszczędności w Galicji w latach 1844-1914. Rzeszów: Oficyna Wydawnicza Politechniki Rzeszowskiej.

Żukowska H. (1989). „Powstanie i rozwój Kas Stefczyka", Annales Universitatis Mariae Curie-Skłodowska, Lublin - Polonia, vol. XXIII, 13. Sectio H, s. 189-204.

\title{
Financial and insurance institutions as the social economy entities in Galicia: An overview
}

\begin{abstract}
Summary: Galicia was the most backward province in the Habsburg monarchy. In the socio-economic structure of this region, the rural population prevailed, sustaining itself on small farms. Natural disasters occurring in Galicia, especially floods and fires, deepened the impoverishment of the society. The emerging social economy entities were aimed at providing aid to various social groups, particularly the rural population. The essay presents the origins and the functioning of cooperative financial institutions and mutual insurance companies in Galicia in the second half of the 19th century. An attempt to assess the results of the activities of cooperative financial institutions showed their important role in counteracting usury and supporting the development of small farms and crafts by providing cheap credit. In the 1860s, the mutual insurance company "Florianka” was established in Kraków. On the eve of World War I this institution was one of the largest societies of this type in the world. In addition, mutual insurance companies „Wisła”, „Dnister" and „Karpatia” were established and operated in Galicia.
\end{abstract}

Keywords: Galicia, credit cooperative, mutual insurance company, social economy, fraternity funds.

\section{Prawa autorskie i licencja / Copyright and License}

Artykuł opublikowano na licencji Creative Commons

Uznanie autorstwa - Użycie niekomercyjne - Bez utworów zależnych 3.0 Polska http://creativecommons.org/licenses/by-nc-nd/3.0/pl/

This article is published under the terms of the Creative Commons Attribution - NonCommercial - NoDerivs (CC BY-NCND 3.0) License http://creativecommons.org/licenses/by-nc-nd/3.0/ 